\title{
MANUEL ACIÉN ALMANSA
}

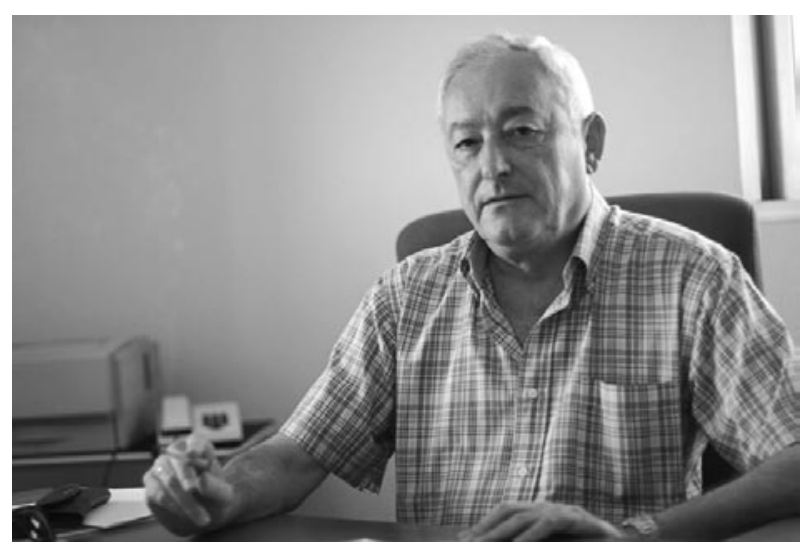

Foto: Jesús Suberbiola

El pasado 5 de agosto, prácticamente ya cerrado el presente volumen de esta revista que él ayudó a fundar y que alentó a mantener en los momentos en que decaía nuestro ánimo, nos llegó la dolorosa noticia del fallecimiento de nuestro amigo Manuel Acién Almansa. Sirva esta apresurada nota como emocionado recuerdo al amigo y maestro, en unos momentos en los que se nos hace muy difícil escribir.

Vicente Salvatierra 